\title{
Gambaran Konsep Diri Pengamen Jalanan
}

\author{
Fitria, Muhammad Zainal Abidin dan Imadduddin \\ Universitas Islam Negeri (UIN) Antasari Banjarmasin
}

\begin{abstract}
Those who are able to judge themselves as poor or called negative self-concept, will always try to stay away in relationships with their surrounding environment or act aggressively unnaturally but not naturally but can judge themselves well or have a positive self-concept and can overcome their problems. whatever problem it will be able to face and will solve it. Based on preliminary studies and previous research, it was found that self-concept is an important concept for interacting with the environment. Therefore, this study aims to determine how the self-concept image of street residents in the Al-Ayjb Foundation includes internal and external dimensions. This study is a qualitative descriptive study, with 3 subjects aged 17-20 years old. The data method used is the interview method, the method of observation and the method of documentation. The results showed that the self-concept image of the street singers at Al-Ayjb Foundation based on the internal dimension tends towards a positive self-concept because of the three subjects expressing opinions or things that are good or positive about themselves while from the external dimension it tends to negative self-concept.
\end{abstract}

Keywords: Self-concept image; street singer.

\begin{abstract}
Abstrak
Mereka yang mampu menilai dirinya kurang baik atau disebut konsep diri negatif, akan selalu mencoba menjauh dalam berhubungan dengan lingkungan disekitarnya atau bertingkah agresif secara tidak wajar namun sebaliknya apabila dia merasa dapat menilai dirinya sendiri dengan baik atau memiliki konsep diri yang positif dan dapat mengatasi permasalahan dirinya maka persoalan apapun itu akan dapat dihadapinya dan akan teratasinya. Berdasarkan studi pendahuluan dan penelitian terdahulu ditemukan hal-hal bahwa konsep diri merupakan konsep penting untuk melakukan interaksi dengan lingkungannya. Oleh sebab itu, penelitian ini bertujuan untuk mengetahui bagaimana gambaran konsep diri pengamen jalanan di Yayasan Al-Ayjb yang meliputi dimensi internal dan eksternal. Penelitian ini merupakan penelitian deskriptif kualitatif, dengan jumlah subjek sebanyak 3 orang yang berusia remaja 17 20 tahun. Metode pengumpulan data yang digunakan adalah metode wawancara, metode observasi dan metode dokumentasi. Hasil penelitian menunjukkan bahwa gambaran konsep diri pada pengamen jalanan di Yayasan Al-Ayjb berdasarkan dimensi internal cenderung ke arah konsep diri yang positif karena dari ketiga subjek lebih mengutarakan pendapat atau halhal yang baik atau positif tentang diri nya sedangkan dari dimensi eksternal cenderung ke arah konsep diri yang negatif.
\end{abstract}

Kata kunci: Gambaran konsep diri; pengamen jalanan. 
Anak adalah sebuah harapan masa depan bangsa yang nantinya akan berpotensi untuk membawa bangsa kita ke arah yang lebih baik atau bahkan sebaliknya, ke arah yang lebih buruk maka dari itu amat sedih lah ketika kita harus melihat seorang anak yang seharusnya bersekolah dan bermain malah sebaliknya, mereka berkerja layaknya orang dewasa. Setiap hari harus berpanas-panasan di sepanjang jalan untuk melakukan pekerjaan untuk menjadi seorang pengamen.

Memiliki pikiran yang positif sangat penting di dalam keseharian seorang pengamen dalam mempertahankan hidup nya. Karena pengamen berusaha semaksimal mungkin dalam mencari uang sebagai sumber penghidupan dan di sisi lain mereka juga menyerahkan semua nya kepada tuhan dan meraka berusaha mencoba untuk tetap berpikir positif untuk dapat menikmati pekerjaannya dan merasa bangga atas apa yang sudah dilakukannya (Shabrina, 2018).

Dengan semakin banyak nya jumlah pengamen yang ada dan berkeliaran di lingkungan masyarakat menyebabkan tidak sedikit masyarakat menjadi resah karena adanya kehadiran mereka yang disebut menganggu dan masyarakat menganggap orang-orang yang berkeliaran di jalanan ialah hanya sebagai sampah. Padahal mereka juga tidak menginginkan untuk menjadi seperti ini. Karena tidak ada orang yang menginginkan hidup di jalanan seperti pengamen tersebut. Pengamen ada yang memiliki dampak baik dan ada juga yang memiliki dampak buruk. Mereka akan berdampak baik apabila mereka akan diterima baik oleh masyarakat sekitar dan mereka juga akan berdampak buruk jika mereka tidak diterima di masyarakat. Bahkan mereka dapat berbuat kriminalitas terhadap masyarakat sekitarnya. Karena pengamen sering dikatakan tidak jauh dari sikap atau perbuatan kriminalitas bahkan penjerumusan ke dunia narkoba dan tidak sedikit masyarakat memandang mereka dengan sebelah mata sehingga situasi ini juga memliki pengaruh dalam pembentukkan konsep diri mereka karena segala sikap dan perilaku mereka akan mempengaruhi konsep dirinya. Pembentukkan konsep diri seseorang bukan hanya didapatkan dari dalam diri sendiri melainkan juga melalui interaksi individu dengan lingkungannya. Maka dari itu mereka harus mampu menyesuaikan konsep diri yang mereka miliki agar mampu diterima oleh masyarakat. 
Konsep diri ialah suatu aspek yang terpenting yang ada di dalam diri seorang individu, karena konsep diri seorang individu ialah suatu konsep penting untuk melakukan interaksi dengan lingkungannya (Fitts, 1971). Mengetahui konsep diri seorang individu, maka akan lebih mudah mengetahui dan memahami perilaku seseorang tersebut. Yang pada dasarnya perilaku seseorang memiliki kaitan dengan gagasan-gagasan tentang dirinya. Apabila individu dapat membuat dirinya sebagai seseorang yang inferior dibandingkan dengan yang orang lain, namun penilaian ini belum tentu kebenarannya biasanya perilaku yang ia perlihatkan akan memiliki hubungan dengan kekurangan yang dipersepsikan secara subjektif (Agustiani, 2018). Chaplin mengatakan bahwa konsep diri ialah suatu penilaian tentang dirinya sendiri penilaian seseorang kepada dirinya, pengevaluasi atau penjelasan tentang seseorang oleh orang yang berkaitan (Chaplin, 1962).

Tujuan dari penelitian ini ialah untuk mengetahui bagaimana gambaran konsep diri pada pengamen jalanan di yayasan Al.Ajyb yang meliputi: Dimensi internal dan Dimensi eksternal. Dimensi internal yaitu: 1). Bagaimana subjek mampu menjelaskan dan menilai identitas diri nya; 2). Bagaimana subjek mampu menjelaskan dan menilai apa yang dilakukan oleh diri nya; 3). Bagaimana subjek mampu bertindak sebagai pengamat dirinya; Dimensi eksternal yaitu: 1). Bagaimana cara subjek memandang atau menilai penampilan fisiknya; 2). Bagaimana subjek mampu memberikan penilaian diri yang berhubungan dengan nilai-nilai moral dan etika; 3). Bagaimana subjek mampu menilai tentang pribadi nya; 4). Bagaimana subjek menilai hubungan subjek dengan keluarganya; 5). Bagaimana subjek menilai hubungan sosial nya dengan orang lain.

Adapun manfaat dari penelitian ini, diantara nya manfaat bagi teoritis ialah penelitian ini diharapkan mampu memiliki manfaat untuk bahan tambah informasi pengembangan studi psikologi yang berhubungan dengan penelitian ini terkait dengan Psikologi Sosial dan Psikologi Komunitas dan manfaat praktis ialah penelitian ini mampu diharapkan sebagai bahan tambah bacaan pembaca agar lebih menambah wawasan tentang konsep diri dan untuk menambah wawasan terhadap lembaga yang terkait seperti; yayasan Al.Ayjb, dinas sosial dan masyarakat umum. 
Di Banjarmasin terdapat beberapa yayasan yang khusus menaungi anak jalanan dan salah satu nya ialah Yayasan Al-Ayjb. Yayasan Al-Ayjb pada awal nya bukanlah sebuah yayasan melainkan sebuah majelis yang didalamnya terdapat 4 orang Anak Jalanan yang ingin belajar tentang agama. Pada tanggal 10 juli 2018 Al-Ayjb resmi menjadi sebuah yayasan Anak Jalanan yang di sahkan oleh Kementrian Hukum dan Hak Asasi Manusia Republik Indonesia. Pengamen jalanan jika mereka diterima dilingkungan masyarakat maka mereka juga bersikap menghormati dan menerima diri sendiri namun sebaliknya jika kehadiran mereka tidak diterima dimasyarakat bahkan ditolak maka mereka juga akan merasa tidak dapat menerima diri sendiri. Walaupun mereka sudah berusaha untuk bersikap baik tapi tetap saja stigma yang melekat pada diri mereka akan mempengaruhi diri pandangan terhadap diri mereka yaitu ke arah yang negatif. Hal ini merupakan hal yang sangat penting karena pengamen jalanan juga merupakan salah satu anak bangsa yang nantinya bangsa ini akan berada ditangan mereka hanya saja saat ini mereka sedang mengalami kesulitan yang mengharuskan mereka melakukan pekerjaan tersebut.

\section{Metode}

Jenis penelitian ini merupakan penelitian kualitatif atau penelitian lapangan dengan metode deskritif kualitatif. Penelitian ini akan mengarah kepada gambaran konsep diri seorang pengamen remaja di Yayasan Al-Ayjb kota Banjarmasin. Adapun pemilihan subjek penelitian didalam penelitian ini dilakukan dengan menggunakan kriteria yang sudah ditentukkan dan kemudian didapatkan 3 orang subjek penelitian. Adapun yang menjadi karakteristik utama subjek didalam penelitian ialah sebagai berikut: a). Subjek masuk pada kategori usia remaja (berusia 14-20 tahun). Karena pada saat usia remaja, seseorang akan lebih dapat berkomunikasi dengan baik untuk memudahkan pada saat wawancara, b). Subjek merupakan pengamen jalanan yang berasal anggota yayasan Al-Ajyb atau yang bertempat tinggal di yayasan Al-Ajyjb. Agar lebih memudahkan peneliti untuk bertemu dengan subjek karena tinggal ditem pat yang tetap, c). Subjek berjenis keamin laki-laki, karena pengamen di Yayasan Al-Ajyb anggota nya seluruhnya berjenis kelamin laki-laki. 
Teknik pengumpulan data yang digunakan ialah wawancara dengan menggunakan guide wawancara yang sudah disediakan dengan professional judgement oleh 3 orang ahli, yaitu: Nur Alina Saidah, M.Psi, Psikolog, Siti Raiyati, M.Psi dan Anida Magfirah, M.Psi, observasi dan dokumentasi sebagai bahan bantu untuk mengingat pembicaraan selama wawancara dan untuk mempermudah nantinya saat pengolahan data agar data yang diberikan sesuai dan benar.

\section{H a $\mathrm{s}$ i 1}

\section{Tabel 1}

Identitas Subjek Penelitian

\begin{tabular}{rccccc}
\hline No & Subjek & $\begin{array}{c}\text { Usia } \\
\text { (th) }\end{array}$ & $\begin{array}{c}\text { Pendidikan } \\
\text { Terakhir }\end{array}$ & Agama & $\begin{array}{c}\text { Lama di } \\
\text { yayasan }\end{array}$ \\
\hline $\mathbf{1}$ & Subjek A & 17 & SMK & Islam & $>3$ bulan \\
$\mathbf{2}$ & Subjek B & 19 & SMA & Islam & $>6$ bulan \\
$\mathbf{3}$ & Subjek C & 20 & SD & Islam & $>6$ bulan \\
\hline
\end{tabular}

Berdasarkan dari hasil data yang telah disajikan melalui proses wawancara pada gambaran konsep diri pengamen jalanan di Yayasan Al-Ayjb Kota Banjarmasin maka dapat diketahui gambaran dari konsep diri yang meliputi dari dua dimensi yaitu dimensi internal dan dimensi eksternal. Pada penelitian ini didapatkan tiga orang subjek dengan gambaran konsep diri yang berbeda-beda. Adapun yang dimaksud dengan konsep diri yang berbeda-beda ialah antara subjek A, B dan C memiliki penilaian atau pandangan diri yang berbeda-berbeda tergantung keyakinan mereka masing-masing. Pada dimensi internal perlu diketahui terlebih dahulu bahwa setiap orang memiliki perilaku dan latar pendidikan yang berbeda-beda begitu pun yang dirasakan oleh ketiga subjek yaitu subjek A, B dan C meski subjek A, B dan C samasama hidup di jalanan namun mereka memiliki keyakinan yang berbeda tentang penilai perilaku mereka yaitu subjek A memiliki penilaian yang positif terhadap perilakunya karena menurut subjek A, subjek A masih memiliki kesempatan untuk memperbaiki perilakunya 
untuk menjadi lebih baik sedangkan subjek B dan C memiliki penilaian yang negatif karena menurut subjek B dan C mereka hidup di jalanan maka mereka akan selalu dipandang tidak baik oleh orang lain.

Adapun pada dimensi eksternal yang menjadi permasalahan yang harus dihadapi pengamen seperti permasalahan tentang aturan pemerintah serta mengenai moral dan etika ketika mengamen. Dari ketiga subjek A, B dan C memiliki pandangan yang sama yaitu mereka memiliki pandangan bahwa subjek A, B dan C memiliki moral dan etika yang negatif terhadap pemerintahan kerena aturan pemerintah yang sangat ketat sedangkan mereka tidak mempunyai pilihan lain maka dari itu subjek A, B dan C selalu melanggar aturan tersebut.

Pengamen jalanan juga menghadapi permasalahan lain yaitu tentang penampilan diri fisik mereka. Setiap orang menilai diri orang lain dari penampilan fisik nya bagaimana cara dia berpenampilan dan berpakaian ketika didepan umum, apabila seseorang mampu berpenam pilan diri yang baik maka orang lain akan menilainya baik namun sebaliknya apabila seseorang berpenampilan tidak baik maka orang lain juga akan menilainya tidak baik. Namun hal itu tidak menjadi hal penting untuk pengamen karena saat mengamen pengamen mempunyai kebebasan untuk memilih berpakaian seperti apa. Begitupun yang dilakukan oleh ketiga subjek. Subjek A, B dan C memiliki gaya berpakaian nya sendiri. Subjek A dan C memiliki pendapat yang sama bahwa ketika mengamen mereka tidak memperdulikan penampilan mereka karena penampilan bukanlah hal yang penting menurut subjek A dan C sedangkan subjek B memiliki pandangan yang berbeda, menurut subjek B meskipun seorang pengamen namun harus tetap mem perhatikan penam pilan karena orang lain pasti melihat dari penampilannya terlebih dahulu.

Pandangan negatif serta diskriminasi dari masyarakat pun sering terjadi karena masyarakat memiliki anggapan bahwa pengamen itu berbeda dengan masyarakat lainnya karena masyarakat lebih banyak menilai bahwa seorang pengamen hanyalah seorang penganggu di jalanan dan merusak ketenangan. Namun hal ini tidak membuat subjek A, B dan C merasa terasingkan bahkan mereka memiliki hubungan sosial yang baik dengan orang lain atau masyarakat umum. Subjek A, B dan C memiliki pandangan yang positif terhadap lingkungan sosial mereka karena menurut subjek A, B dan C memiliki pandangan bahwa masih 
ada orang atau masyarakat yang mampu menerima keadaan mereka sehingga subjek A, B dan $\mathrm{C}$ masih berusaha untuk tetap menjaga hubungan sosial yang baik dengan orang lain.

Keluarga juga menjadi prioritas penting bagi setiap orang dan keluarga juga yang memberikan semangat serta motivasi dalam melakukan pekerjaan apapun. Menjaga hubungan baik dengan keluarga sangat perlu hal itu juga yang dilakukan oleh subjek A, B dan C. Subjek A, B dan C memiliki hubungan yang baik dengan orang tua dan keluarga. Subjek A, B dan C memiliki pandangan yang positif terhadap hubungan mereka kepada orang tua dan keluarga karena menurut subjek A, B dan C semua yang mereka lakukan hanya untuk membahagiakan dan membuat bangga orang tua dan keluarga.

Subjek A, B dan C tinggal terpisah dengan orang tua, subjek A, B dan C tinggal di Yayasan Al-Ayjb yang merupakan salah satu yayasan di Kota Banjarmasin yang membina para pengamen jalanan dalam hal agama maupun ilmu pengetahuan lainnya. Subjek A, B dan C mereka melakukan tugas dan kewajiban mereka dengan baik sebagai anggota yayasan.

Ada perbedaan yang signifikan mengenai kegiatan yang subjek A, B dan C lakukan antara sesudah dan sebelum masuk ke Yayasan Al-Ayjb. Subjek A sebelum masuk ke yayasan kegiatan yang dilakukan subjek lebih ke hal yang tidak ada manfaatnya karena mengikuti pergaulan dari lingkungan dan teman-teman subjek akan tetapi setelah masuk ke yayasan subjek A lebih belajar ke hal yang baik seperti mengikuti pengajian dan kegiatan agama lainnya dan juga kegiatan yang dilakukan subjek B sebelum masuk ke yayasan subjek B lebih merasa nyaman hidup diluar karena subjek B lebih merasakan kebebasan melakukan apapun jika dibandingkan berdiam dirumah dan setelah masuk ke yayasan subjek B mulai belajar tentang tanggung jawab atas pekerjaan yang dilakukan bukan hanya mencari kesenangan dan kebebasan sedangkan subjek C menyatakan tentang kegiatan yang dilakukan sebelum dan sesudah masuk ke Yayasan Al-Ayjb ialah sebelum masuk ke yayasan subjek C lebih merasa tidak mensyukuri keadaan dan pekerjaan yang dilakukan nya saat itu sehingga timbul rasa mengeluh dan protes dalam diri akan tetapi setelah masuk ke yayasan subjek $\mathrm{C}$ lebih belajar untuk menerima dan mensyukuri atas apa yang telah dikerjakan nya dan lebih mengerti bahwa sesuatu yang dilakukannya akan memiliki dampak positif maupun negatif. 
Sebagai seorang yang hidup dan bekerja diluar subjek A, B dan C mengakui bahwa mereka harus mampu menyesuaikan diri dengan apa yang akan mereka hadapi karena mereka akan berhadapan dengan ribuan sifat orang yang berbeda-beda. Oleh karena itu mereka harus mampu menilai atau mengetahui konsep diri mereka agar mereka mampu menyesuaikan dengan lingkungannya.

Adapun ciri khas dari masing-masing subjek, yaitu subjek A dikenal pendiam, subjek B dikenal periang sedangkan subjek $\mathrm{C}$ dikenal dengan sikap tegas namun meskipun berbeda sikap ketiga subjek tetap memiliki persamaan yaitu mereka memiliki sikap tanggung jawab terhadap pekerjaan yang mereka lakukan. Ketika mereka memulai suatu pekerjaan apapun maka akan mereka selasaikan.

\section{Pembahasan}

Seseorang yang memiliki konsep diri positif karena mampu menerima keadaan yang ada pada dirinya dan mampu menerima kekurangan dan kelebihan dirinya sedangkan konsep diri yang negatif mereka tidak mampu menerima keadaan diri nya. Serupa dengan hasil penelitian Sari Nur Azizah mengenai konsep diri homoseksual di kalangan mahasiswa yaitu konsep diri positif karena mampu menerima kondisi yang ada pada dirinya, mampu menerima kekurangan dan kelebihan yang ada dalam dirinya (Azizah, 2013).

Nurfitriani dalam penelitiannya menjelaskan bahwa sebenarnya konsep diri tidak ada yang sepenuhnya bersifat negatif maupun positif hanya saja setiap orang mempunyai konsep diri yang mana lebih dominan dimilikinya (Nurfitriani, 2016). Seperti yang terdapat di Yayasan Al-Ajyb bahwa, konsep diri yang dimiliki antara subjek A, B dan C berbeda-beda ada yang memiliki konsep diri yang positif yaitu gambaran atau pandangan yang baik kedalam diri dan ada yang memiliki konsep diri yang negatif yaitu gambaran atau pandangan yang tidak baik kedalam diri. Tergantung dari keyakinan diri mereka masing-masing yang mana menurut mereka yang lebih dominan dimiliki.

Konsep diri sangatlah penting diketahui khususnya untuk pengamen jalananan karena dengan mengetahui konsep diri atau memiliki pandangan tentang diri kita maka akan memudahkan dalam berinteraksi dengan lingkungan. Hal ini sejalan dengan teori yang 
diungkapkan oleh Yunda Pramucthia dan Nurmala Pandjaitan yang menyatakan bahwa konsep diri ialah salah satu faktor penting untuk membentuk suatu tingkah atau perilaku seseorang. Adapun manfaat seseorang yang mengetahui konsep diri nya ialah agar individu tersebut akan memperlihatkan tingkah laku yang dapat diterima oleh respon dan pandangan yang akan diberikan oleh mereka yang melihatnya (Pamuchtia \& Pandjaitan, 2010).

Masyarakat menganggap orang-orang yang berkeliaran di jalanan ialah hanya sebagai sampah. Padahal mereka juga tidak menginginkan untuk menjadi seperti ini. Karena tidak ada orang yang menginginkan hidup dijalanan seperti pengamen tersebut. Pengamen ada yang memiliki dampak baik dan ada juga yang memiliki dampak buruk. Mereka akan berdampak baik apabila mereka akan diterima baik oleh masyarakat sekitar dan mereka juga akan berdampak buruk jika mereka tidak diterima dimasyarakat. Bahkan mereka dapat berbuat kriminalitas terhadap masyarakat disekitarnya (Singers, 2018). Begitupun yang dirasakan oleh pengamen di Yayasan Al-Ajyb tidak jarang mereka mendapat penolakan dari masyarakat ketika mengamen. Mereka akan berbuat baik apabila mereka diterima dengan baik oleh masyarakat namun sebaliknya mereka akan bersikap tidak baik apabila mereka tidak diterima dengan baik, mereka dijauhi bahkan dicaci maki sehingga dapat menimbulkan mereka berbuat kriminalitas.

Berpikir positif bagi seorang pengamen sangatlah penting. Hal ini sejalan dengan teori yang dikemukkan oleh Dina Nur Shabrina yang mengatakan bahwa memiliki pikiran yang positif sangat penting didalam keseharian seorang pengamen dalam mempertahankan hidup nya (Shabrina, 2018). Karena pengamen berusaha semaksimal mungkin dalam mencari uang sebagai sumber penghidupan dan disisi lain mereka juga menyerahkan semua nya kepada tuhan dan mereka berusah mencoba untuk tetap berpikir positif untuk dapat menikmati pekerjaan nya dan merasa bangga atas apa yang sudah dilakukan nya. Hal itu pun yang dilakukan oleh pengamen di Yayasan Al-Ajyb mereka berusaha untuk memiliki pikiran yang positif terhadap pekerjaan yang mereka lakukan dengan dengan cara merasa bangga dan menikmati pekerjaan yang dilakukan saat ini. 


\section{Kesimpulan}

Berdasarkan uraian diatas, dapat disimpulkan bahwa gambaran konsep diri pengamen jalanan di Yayasan Al-Ayjb kota Banjarmasin, terbagi atas dua dimensi konsep diri yaitu: Yang pertama dimensi internal terdiri dari diri identitas yaitu ketiga subjek memiliki pandangan berbeda atau penilaian berbeda tentang identitas diri nya, mereka ada yang memiliki pandangan positif dan ada yang memiliki pandangan negatif. Mereka memiliki penilaiannya masing-masing tentang identitas diri mereka, diri pelaku yaitu ketiga subjek memiliki pandangan yang sama tentang diri nya sebagai pelaku secara positif, diri penilai yaitu ketiga subjek memiliki penilaian yang positif tentang diri mereka dilihat dari potensi-potensi yang mereka miliki. Yang kedua ialah dimensi eksternal terdiri dari diri fisik yaitu Subjek A dan C memiliki penilaian yang negatif sedangkan subjek B memiliki penilaian yang positif, diri moral dan etika yaitu ketiga subjek memiliki penilaian yang negatif terhadap diri moral dan etika, diri personal yaitu subjek A memiliki penilaian yang positif, subjek B memiliki penilaian yang negatif sedangkan subjek C memiliki penilaian yang relatif, diri keluarga yaitu ketiga subjek memiliki penilaian yang positif terhadap hubungan dengan keluarganya, diri sosial yaitu ketiga subjek memiliki penilaian yang positif terhadap diri sosial nya.

\section{Saran}

Bagi peneliti selanjutnya untuk lebih dapat menyempurnakan penelitian ini sehingga hasil yang diperoleh menjadi jauh lebih akurat. Agar penelitian ini dapat memberikan hasil yang lebih baik dan dapat digeneralisasi perlu menggunakan media pengambilan data yang lengkap seperti menambahkan tes kepribadian yang berkaitan dengan tema yang akan digunakan agar kiranya mampu mengungkap hal-hal yang sulit digali selama proses wawancara dan observasi. Disarankan juga kepada peneliti selanjutnya untuk selalu berusaha menghubungi atau mengunjungi subjek penelitian untuk mengingatkan terkait dengan pengambilan data dan ketika melakukan wawancara dengan subjek, peneliti juga harus mampu menyampaikan wawancara secara jelas agar subjek dapat mengerti. 


\section{Referensi}

Abdurrahman, A. (2011). Sikap Keberagamaan Pengamen Jalanan (Studi Kasus Pengamen Jalanan A. Pangeran Pettarani Makassar).

Abidin, Muhammad Zainal. (2018). Psikologi Profetik dalam Kacamata Filsafat Ilmu: Studi Pemikiran K.H Hamdani Bakran Adz Dzakie. Antasari Press.

Agustina, P. H. (2014). Motivasi Remaja Menjadi Pengamen Jalanan (Studi Deskriptif Pengamen Jalanan di Terminal Benculuk, Kecamatan Cluring, Kabupaten Banyuwangi). Fakultas Ilmu Kesehatan: Universitas Jember.

Alex Sobur. (2013). Psikologi Umum Edisi Revisi. Pustaka Setia.

Burhan Bungin. (2017). Metodologi Penelitian Kuantitatif. Kencana.

Fitts, W. H. (1971). The self-concept and self-actualization. Studies on the Self Concept.

Hendriati Agustiani. (2009). Psikologi Perkembangan (Pendekatan Ekologi Kaitannya dengan Konsep Diri dan Penyesuaian Diri pada Remaja). Refika Aditama.

Khairiah, D. N. (2018). Pengaruh Penilaian Masyarakat Terhadap Self Esteem dan Self Acceptance pada Pengamen. Fakultas Psikologi: Universitas Ahmad Dahlan Yogyakarta.

Pamuchtia, Y., \& Pandjaitan, N. K. (2010). Konsep Diri Anak Jalanan: Kasus Anak Jalanan di Kota Bogor Provinsi Jawa Barat. Sodality: Jurnal Sosiologi Pedesaan.

Shabrina, D. N. (2018). Pengaruh Berpikir Positif Terhadap Komunitas Pengamen. Fakultas Psikologi: Universitas Ahmad Dahlan Yogyakarta .

Singers. (2018). Perilaku Agresif Pada Remaja Pengamen Jalanan. Fakultas Ilmu Sosial: Univesitas Jember.

\begin{tabular}{|l|l|l|l|l|}
\hline Submit & Review & Revisi & Diterima & Publish \\
\hline $09-10-2020$ & - & - & $30-03-2021$ & $22-04-2021$ \\
\hline
\end{tabular}

Fitria, Muhammad Zainal Abidin dan Imadduddin

Program Studi Psikologi Islam

Fakultas Ushuluddin dan Humaniora

Universitas Islam Negeri (UIN) Antasari Banjarmasin

Email : Fitriazha563@gmail.com 